\title{
KEKUATAN SAMBUNGAN LAS THERMIT REL R 54 UNTUK JALUR LINTAS ANGKUTAN BATUBARA
}

\author{
Dwi Purwanto \\ Balai Besar Teknologi Kekuatan Struktur - BPP Teknologi \\ Kawasan PUSPIPTEK Gedung 220 Tangerang Selatan \\ E-mail: dwipurwan@yahoo.co.id
}

\begin{abstract}
Abstrak
Teknologi rel panjang saat ini biasa digunakan pada struktur jalan rel, dimana cara pembuatannya dilakukan dengan menyambung rel-rel standar dengan pengelasan setempat. Las thermit adalah salah satu metode pengelasan yang umum digunakan untuk menyambung rel. Pengelasan pada sambungan rel merupakan titik lemah terutama pada daerah pengaruh panas (HAZ), sebab jika terjadi beban kejut dapat mengakibatkan patah. Persoalan lain adalah mengatasi bahaya tekuk, akibat gaya longitudinal karena perubahan suhu. Makalah ini membahas kajian kekuatan sambungan las thermit rel $R$ 54. Metode evaluasi meliputi pemeriksaan cacat pengelasan, uji kekerasan dan uji kekuatan lentur. Dari hasil uji kekuatan lentur dapat disimpulkan bahwa tegangan rata-rata sambungan rel sebesar $8944,57 \mathrm{~kg} / \mathrm{cm}^{2}$, sedangkan tegangan lentur akibat beban gandar $1193 \mathrm{~kg} / \mathrm{cm}^{2}$ dan tegangan longitudinal akibat perubahan temperatur sebesar $441 \mathrm{~kg} / \mathrm{cm}^{2}$ sampai $1102 \mathrm{~kg} / \mathrm{cm}^{2}$. Dengan demikian sambungan las thermit rel $R 54$ dapat dioperasikan pada lintas angkutan batubara, sepanjang tidak diketemukan adanya indikasi cacat pengelasan.
\end{abstract}

Kata kunci : las thermit, metode kajian, kekuatan sambungan rel.

\begin{abstract}
Long rail technology is now commonly used for a rail track structure, where its manufacture method is carried out by connecting standard rails using in-situ welding. Thermit welding is one of welding methods generally used to joint rails. Welding at rail joint actually is low point of strength especially in heat affected zone, because if there is an impact load the joint can fracture. The other problem is to solve the buckling risk as a consequence of longitudinal force caused by a temperature change. This paper it discusses an assessment of strength of thermit welding at rails $R$ 54. Assessment methods include inspection of welding defect, hardness test and bending strength test. From the bending strength test results, it can be concluded that the average stress of rail joint is $8944,57 \mathrm{~kg} / \mathrm{cm}^{2}$, whereas a bending stress affected by an axle load is 1193 $\mathrm{kg} / \mathrm{cm}^{2}$ and a longitudinal stress caused by the temperature change is $441 \mathrm{~kg} / \mathrm{cm}^{2}$ until $1102 \mathrm{~kg} / \mathrm{cm}^{2}$. Referring to these assessment results, the thermit welding joint at rail $R 54$ is able to operated on the rail track of coal transportation as long as no indication of welding defect.
\end{abstract}

Keyword: thermit welding, assesment method, rail joint strength.

\section{PENDAHULUAN}

Rel merupakan komponen dari struktur jalan kereta api yang pertama kali menerima transfer berat dari rangkaian kereta yang lewat di atasnya. Batang rel terbuat dari baja bertekanan tinggi yang mengandung $0,4-0,82 \% \mathrm{C}, 0,6-1,7 \% \mathrm{Mn}$, $0,05-0,5 \%$ Si, 0,05\% max $S$ dan $0,05 \%$ max $P$. Carbon merupakan unsur yang dominan dalam baja, sedang unsur lain yang memepengaruhi adalah:

* $P$, Mo dan $V$ unsur ini dapat membentuk sifat keuletan pada baja.

* Ni dan Mn unsur ini bersifat memperbaiki sifat keuletan pada baja.

* $P$ akan membuat baja bersifat getas pada suhu rendah. 
* $S$ bersifat menurunkan keuletan baja pada arah tegak.

Standar panjang rel menurut PD 10 th 1986 adalah:

- Rel standar adalah rel yang mempunyai panjang $25 \mathrm{~m}$.

- Rel pendek adalah rel yang mempunyai panjang $100 \mathrm{~m}$.

- Rel panjang adalah rel yang mempunyai panjang minimum $200 \mathrm{~m}$.

Saat ini banyak digunakan teknologi rel panjang (long welded rails), dimana cara pembuatannya dilakukan dengan menyambung rel-rel standar dengan pengelasan setempat. Beberapa teknologi pengelasan rel panjang yang umum dilakukan adalah SMAW, Flass Butt Welding dan Thermit Welding ${ }^{[1]}$.

\section{BAHAN DAN METODE}

\subsection{Bahan Evaluasi}

Evaluasi dilakukan terhadap 4 sampel sambungan las thermit rel $R 54$ yang diambil secara acak dari lokasi proyek pembangunan jalan rel untuk angkutan Batubara. Las thermit adalah proses penggabungan logam dengan cara memanaskan logam secara berlebihan sehingga mencair dengan menggunakan reaksi aluminothermis antara oksida metal dan aluminium. Reaksi yang terjadi secara umum adalah sebagai berikut:

Oksida logam + Bubuk Aluminium ? Aluminium Oksida + Logam + Panar ?.

$3 \mathrm{Fe}_{3} \mathrm{O}_{4}+8 \mathrm{Al}$ ? $9 \mathrm{Fe}+4 \mathrm{Al}_{2} \mathrm{O}_{3} \Delta \mathrm{H}=$ $3350 \mathrm{KJ}$

$3 \mathrm{FeO}+2 \mathrm{Al} ? 3 \mathrm{Fe}+\mathrm{Al}_{2} \mathrm{O}_{3} \cdot \Delta \mathrm{H}=$ $880 \mathrm{KJ}$

$\mathrm{Fe}_{2} \mathrm{O}_{4}+2 \mathrm{Al} ? 2 \mathrm{Fe}+\mathrm{Al}_{2} \mathrm{O}_{3} \cdot \Delta \mathrm{H}=$ $850 \mathrm{KJ}$

Reaksi aluminothermis berlangsung dan selesai apabila afinitas oksigen pada pereduksi (Al) lebih besar dari afinitas oksigen logam yang direduksi (Fe). Panas dihasilkan dari reaksi ekshothermis sebagai hasil dari reaksi $\mathrm{Fe}$ dan $\mathrm{Al}_{2} \mathrm{O}_{3}$. Untuk memulai reaksi diperlukan bubuk penyala atau ignition rod. Ignition rod akan menghasilkan panas untuk meningkatkan bubuk thermit yang akan mengalami kontak pada temperatur sekitar $2200^{\circ} \mathrm{F}$. Untuk menyelesaikan proses pengelasan selain harus dibersihkan dari karat, grease dan kotoran, juga pada bagian ujung harus dipanasi terlebih dahulu untuk menciptakan kondisi yang baik agar terjadi penggabungan antara cairan baja dan logam induk.

Pengelasan dilakukan dengan mengikuti prosedur sebagai berikut:

1. Atur jarak celah rel yang akan disambung sekitar $22-25 \mathrm{~mm}$.

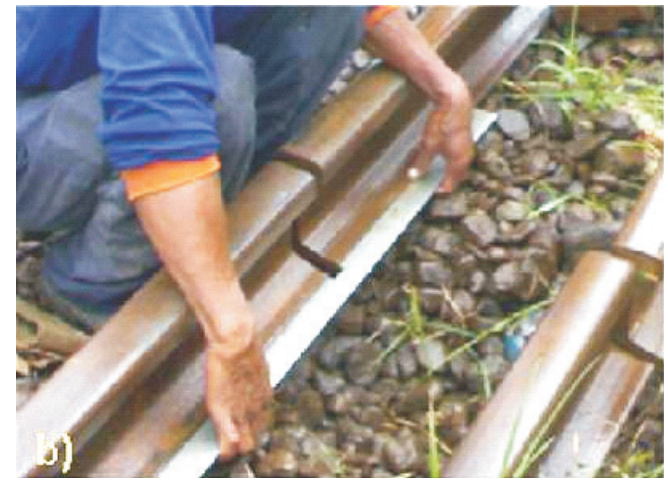

Gambar 1: Mengatur jarak celah.

\section{Pasang cetakan disekitar sambungan}

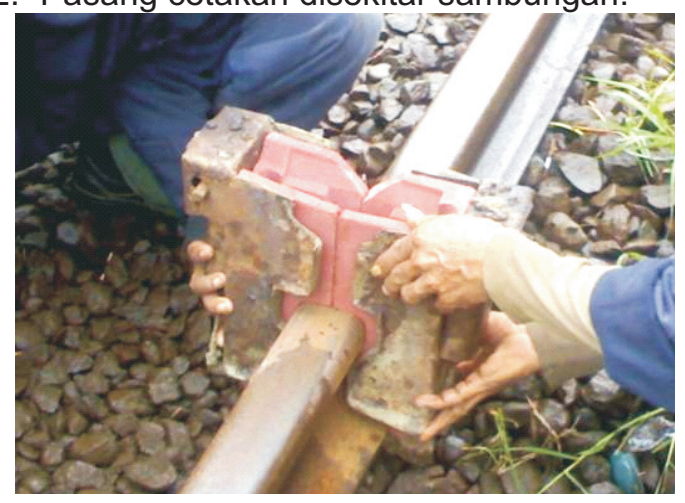

Gambar 2: Memasang cetakan dilokasi sambungan.

3. Isi tempat peleburan (curcible) dengan oksida logam dan bubuk aluminium.

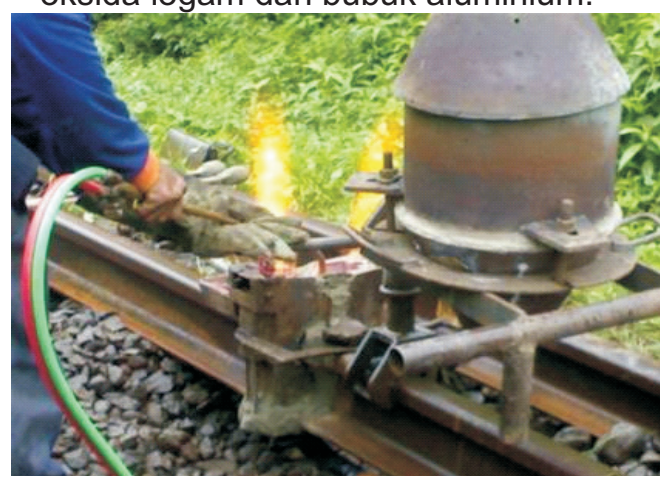

Gambar 3 : Curcible berisi oksida logam dan bubuk aluminium. 
Dalam pengelasan thermit proporsi dari campuran terdiri dari tiga bagian besi oksida dan satu bagian aluminium. Elemen-elemen paduan dapat ditambahkan kedalam persenyawaan thermis untuk mencocokan bagian yang di las. Campuran thermit yang biasa digunakan untuk tipe baja rel adalah baja C-Mn, Cr-Mo dan juga Cr-V. Penambahan tersebut dapat menurunkan jumlah posfor pada baja yang dihasilkan pada proses thermit.

1. Panaskan campuran menggunakan brander sampai $900^{\circ} \mathrm{C}$.

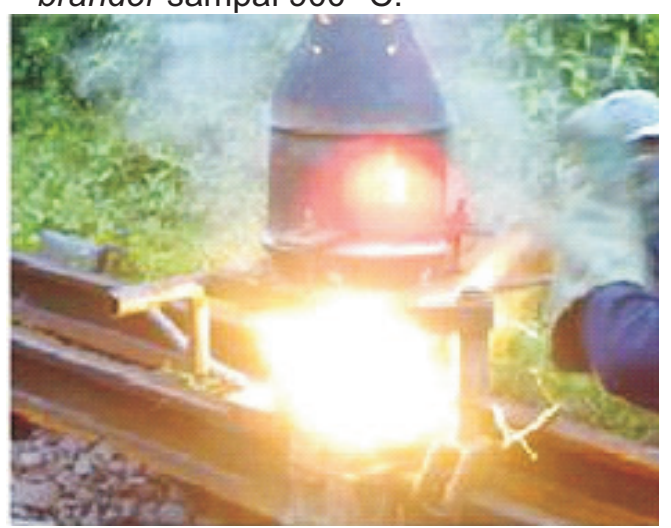

Gambar 4 : Pemanasan menggunakan brander.

Pada suhu $900^{\circ} \mathrm{C}$ ini akan tercetus reaksi ekshothermis dan berlangsung selama kurang lebih 15 menit. Dalam pada itu temperatur reaksi akan mencapai $2500^{\circ} \mathrm{C}$.

2. Buka cetakan dan bersihkan kelebihan besi hasil reaksi menggunakan gerinda.

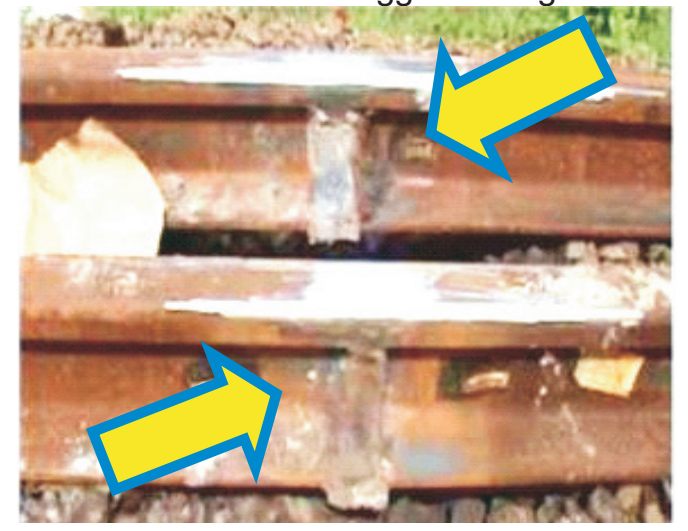

Gambar 5: Hasil sambungan rel las thermit.

Kualitas pengelasan thermit pada hakekatnya bergantung pada kemampuan tukang las dalam mengikuti cara dan metode pengelasan yang dianjurkan.

\subsection{Metode Pengujian}

meliputi:

Metode pengujian yang dilakukan

- Permeriksaan cacat pengelasan

- Uji kekerasan

- Uji kekuatan lentur sambungan las

\subsubsection{Pemeriksaan Cacat Pengelasan}

Tujuan pemeriksaan adalah untuk mendeteksi adanya discontinuity, disintegrity serta unhomogenity hasil pengelasan baik dipermukaan maupun di dalam bahan logam. Pemeriksaan cacat pengelasan dilakukan dengan metode impuls echo ${ }^{[2]}$. Metode ini didasarkan pada prinsip bahwa bilamana impul gelombang yang dipancarkan oleh probe merambat kedalam benda, maka sebagian dari impul gelombang akan direfleksikan oleh permukaan yang lain atau cacat, kemudian kembali ke probe lagi. Impul gelombang yang kembali ke probe akan dirubah menjadi electrical impuls yang dalam layar oscilloscope ditunjukan oleh spot dimana kecepatannya dapat diatur sesuai dengan keperluan.

Adapun prosedur yang dilakukan adalah sebagai berikut:

1. Pemeriksaan peralatan dilakukan terhadap :

$>$ Linieritas skala horisontal (toleransi \pm $10 \%$ divisi skala pembacaan).

$>$ Linieritas skala vertikal (toleransi $\pm 5 \%$ pada $20 \%$ - $80 \%$ FSH /full scale hight)

$>$ Linieritas Gain (toleransi $\pm 20 \%$ perbandingan amplitudo nominal).

$>$ Resolusi

2. Kalibrasi probe

Kalibrasi probe dilakukan menggunakan angle beam calibration block $\left(\mathrm{V}_{1} / \mathrm{N}_{2}\right.$ blok $)$, dengan prosedur sebagai berikut:

$>$ Kalibrasi probe $70^{\circ}$ sesuai dengan ketebalan basic calibration block menggunakan rumus:

$$
\text { Cal }=\frac{2 T}{\operatorname{Cos} 70^{\circ}}
$$

$\mathrm{T}=$ thickness of calibration block

> Tentukan faktor kalibrasi menggunakan rumus:

$F_{k}=\frac{T R}{D I V}$

$\mathrm{TR}=$ test range

Div = division 
$>$ Letakan probe mengarah ke kuadran 25 dari angle beam calibration block, atur posisi pulsa menggunakan tombol sweep range \& sweep delay pada posisi:

$$
\begin{aligned}
S_{1} & =\frac{25 \mathrm{~mm}}{F_{k}} \\
S_{2} & =\frac{25 \mathrm{~mm}+(50 \mathrm{~mm}+25 \mathrm{~mm})}{F_{k}}
\end{aligned}
$$

$>$ Letakan probe mengarah ke kuadran 50 dari angle beam calibration block, atur posisi pulsa menggunakan tombol sweep range \& sweep delay pada posisi:

$$
S_{1}=\frac{50 m m}{F_{k}}
$$

\section{Pemeriksaan cacat}

Pemeriksaan cacat dilakukan dengan scaning pada scaning area dengan mangamati adanya indikasi pulsa cacat. Dengan ketentuan sebagai berikut:

* Pulsa cacat 0 s/d 25\% DAC (distance amplitude curve) atau $20 \%$ full scale high abaikan.

* Pulsa cacat 25 s/d $50 \%$ DAC atau 40\% full scale high harus di analisa.

* Pulsa cacat $50 \mathrm{~s} / \mathrm{d} 100 \%$ DAC atau 80\% full scale high harus di reparasi.

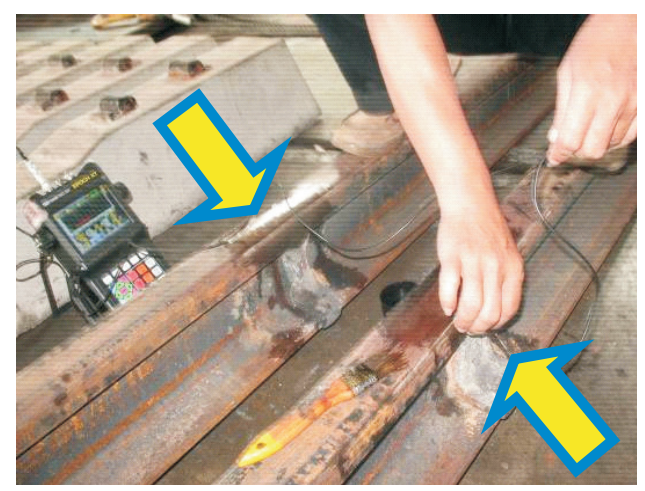

Gambar 6 : Pemeriksaan cacat pengelasan.

\subsubsection{Uji Kekerasan}

Tujuan uji kekerasan adalah untuk mengetahui perubahan struktur logam akibat panas melalui kekerasannya. Uji kekerasan dilakukan menggunakan peralatan "Proceq Equotip Hardness Tester".

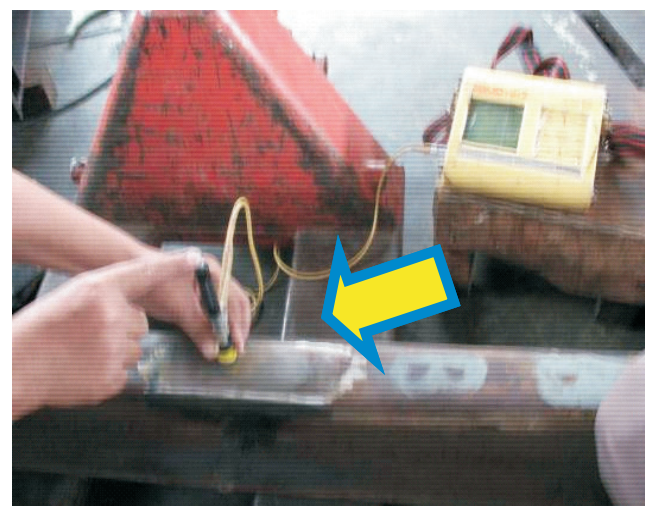

Gambar 7 : Uji kekerasan.

Prosedur uji kekerasan yang dilakukan adalah sebagai berikut:

1. Penggerindaan permukaan benda uji. Pada tingkat pekerjaan ini dipakai mesin gerinda manual, sedangkan sebagai medium digunakan kertas ampelas silicon carbit $(\mathrm{SiC})$ dengan berbagai tingkat kekasaran yaitu kombinasi dari $100,220,320,500,600,800,1000$ \& 1200. Dalam proses ini pertama-tama dipakai kertas ampelas yang paling kasar dengan goresan yang kasar kemudian berangsur-angsur dipakai kertas ampelas yang paling halus sampai pada hasil akhir dari proses penggerindaan diperoleh permukaan dengan goresan yang halus searah dan homogen. Untuk menghindari timbulnya panas, selama penggerindaan berlangsung selalu dialiri dengan air bersih secara terus menerus.

2. Pencucian.

Dalam proses pencucian ini digunakan aceton, karena sambungan las thermit termasuk bahan yang porous ataupun mengandung retakan dan jenis cacat lainnya.

3. Pengujian kekerasan dilakukan pada daerah base metal, weld metal dan pada daerah H A Z (heat affected zone). Hal ini dilakukan dengan tujuan untuk mendapatkan distribusi kekerasan pada setiap titik dari masing-masing benda uji.

\subsubsection{Uji Kekuatan Lentur}

Tujuan uji kekuatan lentur adalah untuk mengetahui kekuatan sambungan rel dalam menerima beban tekan statis. 


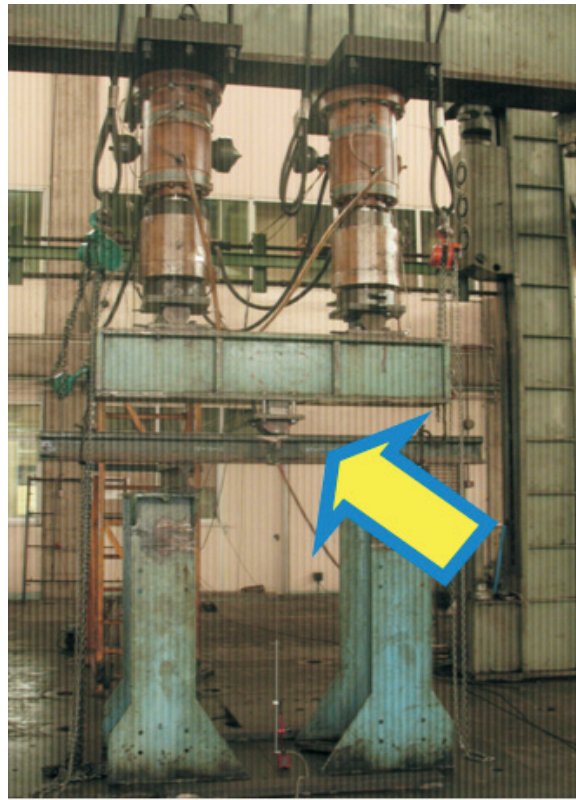

Gambar 8: Set up uji lentur.
Prosedur uji lentur adalah sebagai berikut:

1. Set up benda uji dengan posisi seperti ditunjukan pada gambar 8: Set Up uji lentur.

2. Ditengah bentang benda uji dipasang displacement transducer untuk mengukur defleksi benda uji.

3. Beban dibangkitkan melalui ramp generator dengan laju pembebanan konstan hingga mencapai beban maksimum yang mampu ditahan benda uji.

4. Selama pengujian berlangsung dilakukan perekaman grafik Gaya Vs Defleksi menggunakan $\mathrm{X}-\mathrm{Y}$ recorder.

5. Beban maksimum ditunjukan pada kurva, dimana kedudukan kurva pada titik maksimum sedang beban yang diijinkan ditunjukan pada daerah linier darikurva.

\section{HASIL DAN PEMBAHASAN}

\subsection{Hasil Pengujian}

Tabel 1 : Hasil pemeriksaan cacat pengelasan

\begin{tabular}{|c|c|c|c|c|c|c|}
\hline \multicolumn{3}{|c|}{ Identification Number } & Rel 1 & Rel 2 & Rel 3 & Rel 4 \\
\hline \multicolumn{3}{|c|}{ Transducer Angle } & $0^{\circ} \& 70^{\circ}$ & $0^{\circ} \& 70^{\circ}$ & $0^{\circ} \& 70^{\circ}$ & $0^{\circ} \& 70^{\circ}$ \\
\hline & & From Face & $A \& B$ & $A \& B$ & $A \& B$ & $A \& B$ \\
\hline \multirow{4}{*}{$\begin{array}{l}\frac{\omega}{d} \\
\frac{0}{0} \\
\frac{0}{0} \\
\frac{0}{0} \\
0\end{array}$} & Indication Level & a & - & - & - & - \\
\hline & Reference Level & $b$ & 46 & 46 & 46 & 46 \\
\hline & Attenuation Factor & c & 2 & 2 & 2 & 2 \\
\hline & Indication Rating & $d$ & 19 & 19 & 19 & 19 \\
\hline \multirow{6}{*}{ 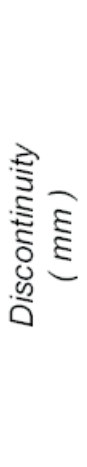 } & & Length & 25 & - & - & - \\
\hline & Angular Distance & Sound Path) & 17 & - & - & - \\
\hline & \multicolumn{2}{|c|}{ Depth from Ä Surface } & 6 & - & - & - \\
\hline & \multirow{2}{*}{ Distance } & From X & - & - & - & - \\
\hline & & From Y & - & - & - & - \\
\hline & \multicolumn{2}{|c|}{ Discontinuity Evaluation } & IF & $\mathrm{NI}$ & NI & $\mathrm{NI}$ \\
\hline \multicolumn{3}{|r|}{ Remarks } & $R$ & $A$ & $A$ & $A$ \\
\hline
\end{tabular}


Tabel 2: Hasil uji kekerasan

\begin{tabular}{|c|c|c|c|c|}
\hline \multirow{2}{*}{ No } & \multirow{2}{*}{ Benda Uji } & \multicolumn{3}{|c|}{ Nilai Kekerasan ( $H B$ ) } \\
\hline & & Base Metal & Heat Affected Zone & Weld Metal \\
\hline \multirow{3}{*}{1} & \multirow{3}{*}{ Rel 1} & 276 & 322 & 320 \\
\hline & & 270 & 315 & 314 \\
\hline & & 270 & 315 & 312 \\
\hline & Rata-rata & 272 & 317 & 315 \\
\hline \multirow{3}{*}{2} & \multirow{3}{*}{ Rel 2} & 266 & 311 & 307 \\
\hline & & 276 & 315 & 308 \\
\hline & & 270 & 317 & 311 \\
\hline & Rata-rata & 270 & 314 & 308 \\
\hline \multirow{3}{*}{3} & \multirow{3}{*}{ Rel 3} & 269 & 310 & 304 \\
\hline & & 272 & 309 & 293 \\
\hline & & 270 & 311 & 305 \\
\hline & Rata-rata & 270 & 310 & 300 \\
\hline \multirow{3}{*}{4} & \multirow{3}{*}{ Rel 4} & 269 & 310 & 304 \\
\hline & & 269 & 310 & 295 \\
\hline & & 270 & 311 & 303 \\
\hline & Rata-rata & 269 & 309 & 300 \\
\hline
\end{tabular}

Tabel 3 : Hasil uji kekuatan lentur

\begin{tabular}{|c|c|c|c|c|}
\hline No & Benda Uji & Beban $(\mathrm{kN})$ & Defleksi $(\mathrm{mm})$ & Tegangan $\mathrm{kg} / \mathrm{cm}^{2}$ \\
\hline 1. & Rel 1 & 554 & 4,5 & 4498,59 \\
\hline 2. & Rel 2 & 1071 & 8,5 & 8696,73 \\
\hline 3. & Rel 3 & 1108 & 8,5 & 8928,68 \\
\hline 4. & Rel 4 & 1134 & 9,0 & 9208,31 \\
\hline
\end{tabular}

$1 \mathrm{kN}=101,9716 \mathrm{~kg}$

Tegangan lentur dihitung menggunakan persamaan:

$$
\begin{gathered}
\sigma=\frac{M_{O} \bar{Y}}{I_{x}} \\
M_{o}=1 / 4 F L
\end{gathered}
$$

$\sigma=$ Tegangan lentur $\left(\mathrm{kg} / \mathrm{cm}^{2}\right)$

$M_{o}=$ Momen lentur (kg.cm)

$\bar{Y}=$ Jarak tepi bawah rel ke garis netral $(7,62 \mathrm{~cm})$

$I_{x}=$ Momen Inersia $\left(2346 \mathrm{~cm}^{4}\right)$

$F=$ Beban lentur

$L=$ Jarak tumpuan $(100 \mathrm{~cm})$

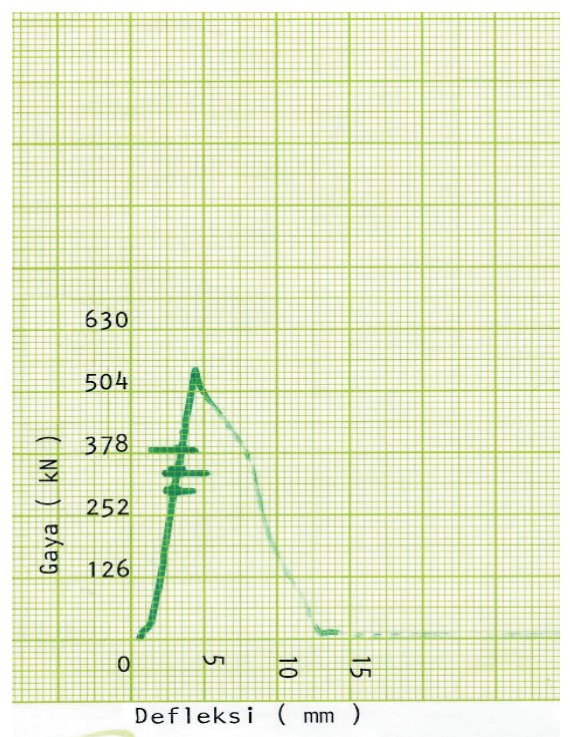

Gambar 9 : Grafik Gaya Vs Defleksi Rel 1 


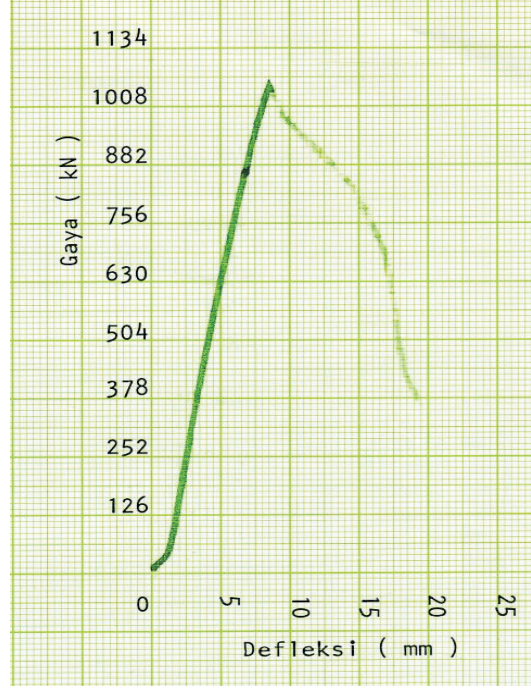

Gambar 10 : Grafik Gaya Vs Defleksi rel 2

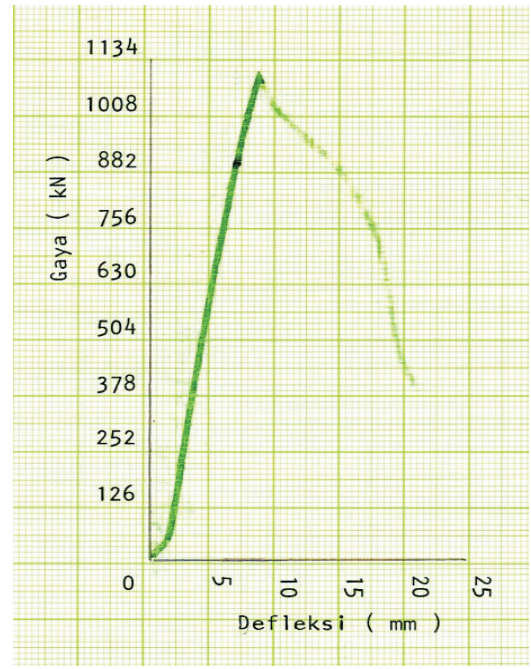

Gambar 11: Grafik Gaya Vs Defleksi Rel 3

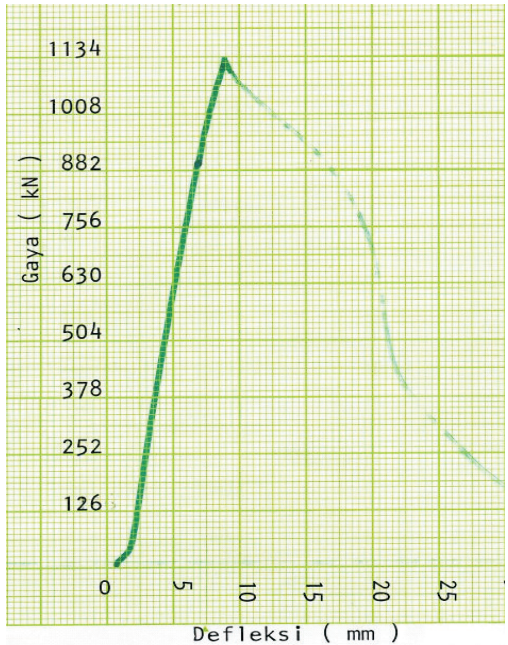

Gambar 12: Grafik Gaya Vs Defleksi Rel 4

\subsection{Pembahasan}

Dalam struktur jalan rel gaya vertikal merupakan beban yang paling dominan. Gaya vertikal berasal dari beban gandar (lokomotif, kereta, gerbong dan lain-lain). Gaya ini akan menyebabkan defleksi vertikal pada rel. Pada lintas angkutan batubara digunakan Lokomotif CC 202 dengan kecepatan rata-rata $120 \mathrm{~km} / \mathrm{jam}$ dan Gerbong KKBW dengan berat muatan batubara 50 ton.

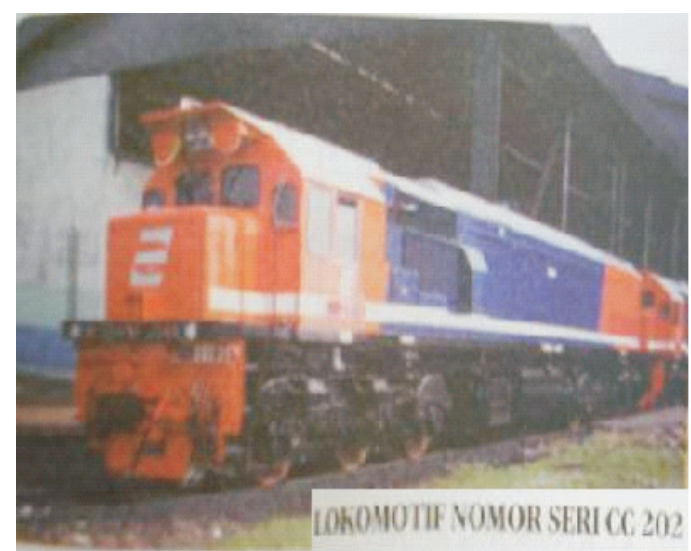

Berat lokomotif CC $202=108$ ton

Jumlah gandar $=6$

Beban gandar $=108 / 6=18$ ton

Beban 1 roda $=18 / 2=9$ ton

Gambar 13 : Lokomotif CC 202.

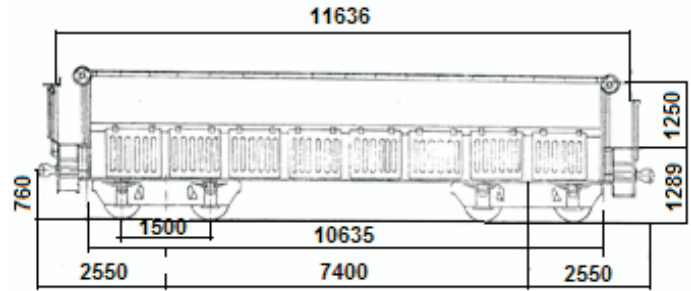

Berat gerbong $\mathrm{KKBW}=22$ ton

Berat muatan $\quad=50$ ton

Berat total $\quad=72$ ton

Jumlah gandar $=4$

Berat gandar $=72 / 4=18$ ton

Beban 1 roda $=18 / 2=9$ ton

Gambar 14 : Gerbong KKBW

Dalam perhitungan, rel dianggap sebagai suatu balok tidak berhingga panjangnya dengan pembebanan beban terpusat dan ditumpu oleh struktur dengan modulus elastisitas jalan rel (track stiffness) yang besarnya $180 \mathrm{~kg} / \mathrm{cm}^{2}$. Transformasi beban roda dinamis dihitung menggunakan persamaan TALBOT ${ }^{[3]}$ : 
Persamaan TALBOT:

$P_{d}=P+0,01 P(V-5)$

$P_{d}=$ beban dinamis roda

$P=$ beban roda

$V=$ kecepatan $(\mathrm{mil} / \mathrm{jam})$

$P_{d}=\left[9000+0,01.9000\left(\frac{120}{1,609}-5\right)\right]$

$=15262,24 \mathrm{~kg}$

Besarnya momen lentur dihitung menggunakan persamaan:

$M_{o}=\frac{P_{d}}{4 \lambda}$

$\lambda=$ dumping factor

$\lambda=\sqrt[4]{\frac{k}{4 E I}}$

$k=$ track stiffness $\left(180 \mathrm{~kg} / \mathrm{cm}^{2}\right)$

$E=$ elasticity moduls $\left(2,1 \times 10^{6} \mathrm{~kg} / \mathrm{cm}^{2}\right)$

$I_{x}=$ Inertia moment $\left(2346 \mathrm{~cm}^{4}\right)$

$$
\lambda=\sqrt[4]{\frac{180}{4 \cdot 2,1 \cdot 10^{6} \cdot 2346}=0,0098 \mathrm{~cm}^{-1}}
$$

Diperoleh harga momen lentur:

$M_{o}=\frac{15262,2}{4.0,0098}=432150,50 \mathrm{kgcm}$

Besarnya tegangan lentur:

$\sigma=\frac{M_{i} \bar{Y}}{I_{x}}$

$M_{i}=0,85 M_{o}$, Momen lentur akibat super posisi beberapa gandar.

$\bar{Y}$ Jarak tepi bawah rel ke garis netral

$$
\begin{aligned}
\sigma & =\frac{0,85.4322150,50.7,62}{2346} \mathrm{~kg} / \mathrm{cm}^{2} \\
& =1193 \mathrm{~kg} / \mathrm{cm}^{2}
\end{aligned}
$$

Disamping gaya vertikal pada konstruksi jalan rel dimana dipakai teknologi rel panjang, gaya longitudinal harus diperhitungkan. Gaya ini terutama disebabkan oleh perubahan suhu pada rel (thermal strees) $)^{[4]}$. Selain itu gaya longitudinal juga disebabkan oleh gaya adhesi akibat gesekan roda dan rel serta gaya rem akibat pengereman kendaraan rel.

Di dalam ilmu fisika bahwa perubahan panjang $\Delta \mathrm{L}$ adalah sebanding dengan:

- Panjang rel (L)

- Perubahan temperatur $(\Delta \mathrm{t})$

- Koeffisien muai panas (á)

$\Delta L=L \alpha \Delta t$

Menurut Hukum Hooke: Bila ada suatu gaya $F$, pemuaian suatu balok adalah berbanding lurus dengan panjang balok dan berbanding terbalik dengan luas penampang melintang.

$\Delta L=k \frac{F . L}{A}$

$k=\frac{1}{E} \quad ? \quad \Delta L=\frac{1}{E} \frac{F \cdot L}{A}=\frac{F L}{E A}$

$F=\frac{E A \cdot \Delta L}{L}$, Oleh karena $\Delta L=L \alpha \Delta t$

$F=\frac{E A L \alpha \Delta t}{L} ? \quad F=E A \alpha \Delta t$

$\Delta l \quad=$ perubahan panjang

$F \quad=$ gaya yang bekerja

$L=$ panjang rel

$A \quad=$ penampang rel

$k=$ konstanta

$\alpha^{\prime}=$ koeffisien muai $\left(10,5 \times 10^{-6}\right)$

Panjang sambungan rel umumnya dibuat $800 \mathrm{~m}$, sedangkan perubahan temperatur rel antara $20^{\circ} \mathrm{C}$ hingga $50^{\circ} \mathrm{C}$. Dengan demikian gaya yang ditimbulkan akibat perubahan temperatur dapat dihitung.

Panjang rel $=800 \mathrm{~m}=80.000 \mathrm{~cm}$. Perubahan temperatur $20^{\circ} \mathrm{C}$. Luas penampang melintang rel R $54=6934 \mathrm{~mm}^{2}$

Jadi perubahan panjang:

$\Delta L=L \alpha \Delta t$

$\Delta L=80.000 \times 10,5 \times 10^{-6} \times 20=16,8 \mathrm{~cm}$

$F=E A \alpha \Delta t$

$=2,1 \cdot 10^{6} \times 69,34 \times 10,5 \cdot 10^{-6} \times 20$

$F=30578,94 \mathrm{~kg}$

$\sigma=\frac{F}{A}=\frac{30578,94}{69,34}=441 \mathrm{~kg} / \mathrm{cm}^{2}$

Untuk perubahan temperatur $\mathrm{t}=50^{\circ} \mathrm{C}$

$F=76447,35 \mathrm{~kg} 9208,31$

$\sigma=1102 \mathrm{~kg} / \mathrm{cm}^{2}$ 


\section{KESIMPULAN}

Dari hasil pengujian yang telah dilakukan dapat diambil kesimpulan bahwa:

- Sebelum dioperasikan setiap sambungan rel harus dilakukan pemeriksaan untuk memastikan tidak adanya cacat pengelasan yang dapat mengakibatkan berkurangnya kekuatan dalam menahan beban.

- $\quad$ Kekerasan rata-rata pada daerah HAZ (Heat Affected Zone) sebesar 309 hingga $317 \mathrm{HB}$. Hal ini masih sesuai dengan standar kekerasan yang ditetapkan Direktorat Jalan \& Bangunan Kantor Pusat PJKA yaitu sebesar 280 hingga $334 \mathrm{HB}^{[5]}$.

- $\quad$ Tegangan lentur untuk Rel 2, Rel 3 dan Rel 4 masing-masing sebesar 8696,73 $\mathrm{kg} / \mathrm{cm}^{2}, 8928,68 \mathrm{~kg} / \mathrm{cm}^{2}$ dan 9208,31 $\mathrm{kg} / \mathrm{cm}^{2}$. Rata-rata $8944,57 \mathrm{~kg} / \mathrm{cm}^{2}$ sementara tegangan lentur akibat beban gandar yang diperoleh dari hasil perhitungan sebesar $1193 \mathrm{~kg} / \mathrm{cm}^{2}$ dan tegangan longitudinal akibat perubahan temperatur sebesar 1102 $\mathrm{kg} / \mathrm{cm}^{2}$. Dengan demikian sambungan las thermit rel R 54 dapat dioperasikan pada lintas angkutan batubara, sepanjang tidak diketemukan adanya indikasi cacat pengelasan, meskipun tidak dapat dipungkiri bahwa kemampuan material dari suatu konstruksi selalu memiliki kekuatan menahan beban dinamis yang jauh lebih rendah dari kekuatan menahan beban statis.

\section{DAFTAR PUSTAKA}

1. Wiryosumarto, H., Okumura, T. Teknologi Pengelasan Logam, Pradya Paramita, Jakarta 2010.

2. Blitz, J., Simpson G., Ultrasonic Method of Non-Destructive Testing, First Edition 1996

3. Penjelasan Peraturan Dinas No. 10 Perencanaan Konstruksi Jalan Rel, 2009.

4. Soebagio, P. Prinsip-prinsip Rel Panjang Menerus, Asosiasi Profesi Perkeretaapian Indonesia, Bandung 2010.

5. Direktorat Jalan \& Bangunan Kantor Pusat PJKA, 1989.

\section{LAMPIRAN}

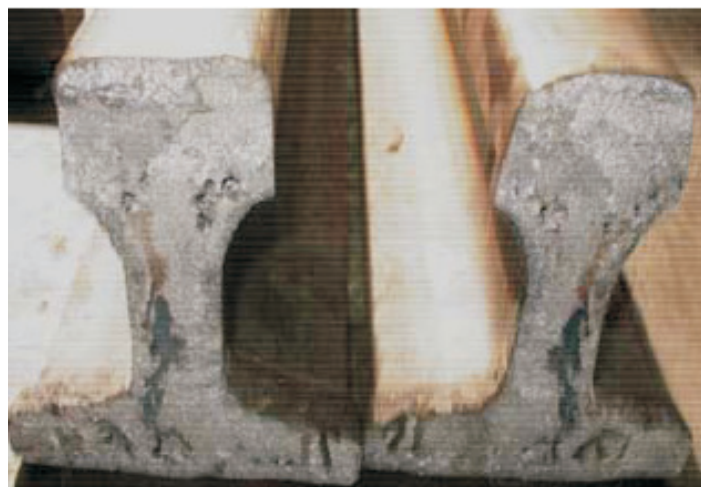

Gambar 15: Penampang patahan benda uji dengan cacat Slag Inclusion

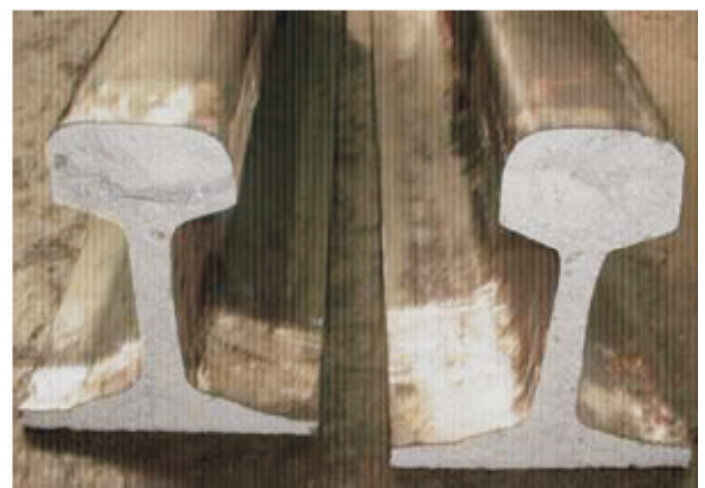

Gambar 16: Penampang patahan benda uji dengan sedikit void

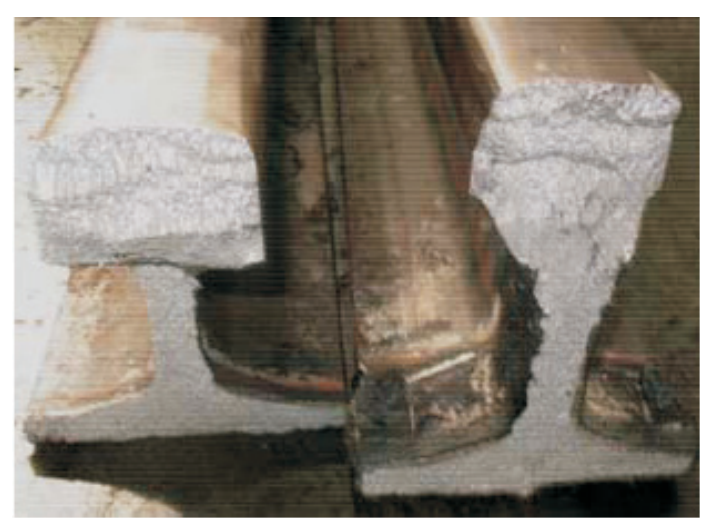

Gambar 17 : Penampang patahan benda uji tanpa cacat pengelasan

\section{RIWAYAT PENULIS}

Dwi Purwanto, lahir di Purbalingga 08 Desember 1957. Menamatkan pendidikan Sarjana Teknik Fisika tahun 2005 di Sekolah Tinggi Teknologi Mutu Muhammadiyah. Bekerja di BPP Teknologi sejak tahun 1983. Saat ini bekerja sebagai Staf Bidang Kajian Struktur di Balai Besar Teknologi Kekuatan Struktur-BPP Teknologi. 